\title{
Compressive Strength of Concrete by Using Coconut Shell
}

\author{
Parag S. Kambli ${ }^{1}$, Sandhya R. Mathapati ${ }^{2}$ \\ ${ }^{I}$ (PG Student, Department of Civil Engineering, DYPSOET, University of Pune, Pune - 411014 \\ ${ }_{2}^{2}$ (Guide \& Assistant Prof., Department of Civil Engineering, DYPSOET, University of Pune, Pune - 411014
}

\begin{abstract}
The high cost of conventional construction materials is a dominating factor affecting housing system around the world. This has necessitated research work into alternative materials in the construction field. Conventional coarse aggregate namely gravel and fine aggregate is sand in concrete will be used as control. While natural material is coconut shell as course aggregate will be investigate to replace the aggregate in concrete. In this study, three different concrete mixes namely M20, M35 \& M50 grade with different combination of natural material CS content in the proportion $0 \%, 10 \%, 20 \%, 30 \%$ and $40 \%$ will be replaced. Six sample specimen will be prepared for each concrete mixes. The parameters will be tested are compressive strength behaviour of cube specimens for $7 \& 28$ days.

The main objective is to encourage the use of these 'seemingly' waste products as construction materials in lowcost housing. It is also expected to serve the purpose of encouraging housing developers in investing these materials in house construction.
\end{abstract}

Keywords: - Coarse aggregates, Coconut shell, Compressive strength, Concrete cube specimens, Grade 53 Birla cement, M20, M35, M50, CTM, etc.

\section{INTRODUCTION}

Following a normal growth in population, the amount and type of waste materials have increased accordingly. Many of the non-decaying waste materials will remain in the environment for hundreds, perhaps thousands of years. The non-decaying waste materials cause a waste disposal crisis, thereby contributing to the environmental problems. However, the environmental impact can be reduced by making more sustainable use of this waste. This is known as the Waste Hierarchy. Its aim is to reduce, reuse, or recycle waste, the latter being the preferred option of waste disposal.

\subsection{Concrete:}

Versatility of making concrete with locally available materials, ease in moulding it into any shape and size and economy in its making has made concrete the 2nd largest consumed material on earth.

a. Far more concrete is produced than any other man-made material. Annual production represents one ton for every person on the planet.

b. It is incredibly versatile, and is used in almost all major construction projects.

c. Aggregates are used in concrete for very specific purposes. Aggregates typically make up about $60 \%$ to $75 \%$ of the volume of a concrete mixture, and as they are the least expensive of the materials used in concrete, the economic impact is significant.

d. $80 \%$ of buildings $\mathrm{CO}_{2}$ emissions are generated not by the production of the materials used in its construction, but in the electric utilities of the building over its life-cycle.

e. Compared to other comparable building materials, concrete is less costly to produce and remains extremely affordable.

\subsection{Use of waste in concrete:}

A research effort has been done to match society's need for safe and economic disposal of waste materials. The use of waste materials saves natural resources and dumping spaces, and helps to maintain a clean environment. The current concrete construction practice is thought unsustainable because, not only it is consuming enormous quantities of stone, sand and drinking water, but also two billion tons a year of Portland cement, which releases green-house gases leading to global warming. Experiments has been conducted for waste materials like- rubber tyre, e-waste, coconut shell, blast furnace slag, waste plastic, demolished concrete constituents, waste water etc. Construction waste recycle plants are now installed in various countries but they are partly solution to the waste problems. 


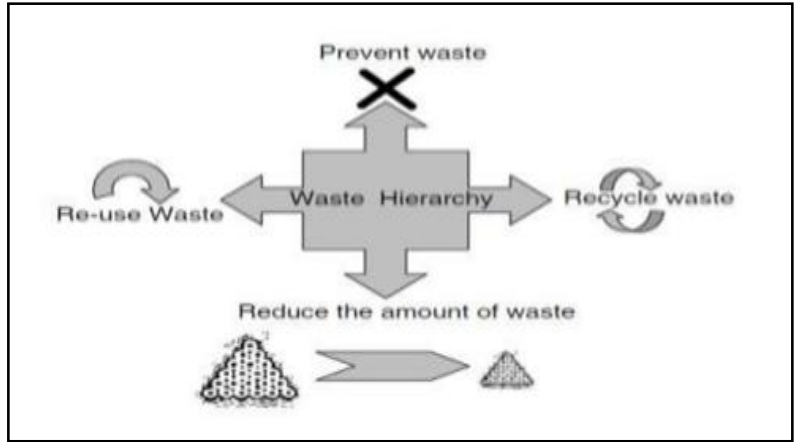

Figure 1: Waste Hierarch

\section{COCONUT SHELL AS AGGREGATE}

Coconut shell particles are used as reinforcing material for investigation. Shell particles of size between $20 \mathrm{~mm}-600 \mu$ are prepared in grinding machine. Coconut shell aggregates are potential candidates for the development of new composites because of their high strength and modulus properties. An approximate value of coconut shell density is $1.60 \mathrm{~g} / \mathrm{cm}^{3}$.

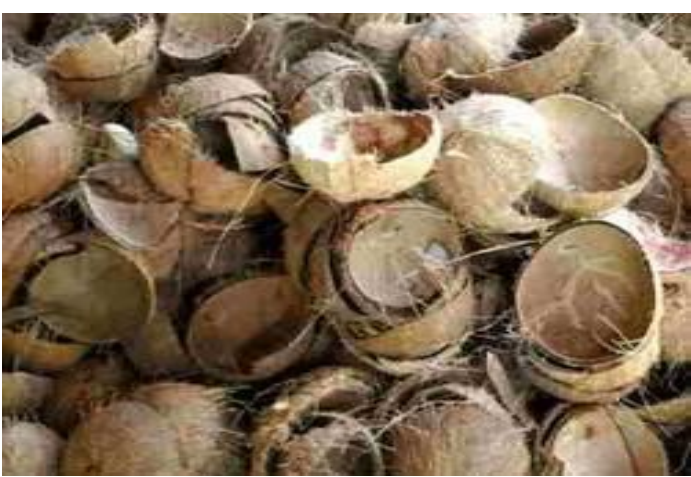

Figure 2: Coconut Shell

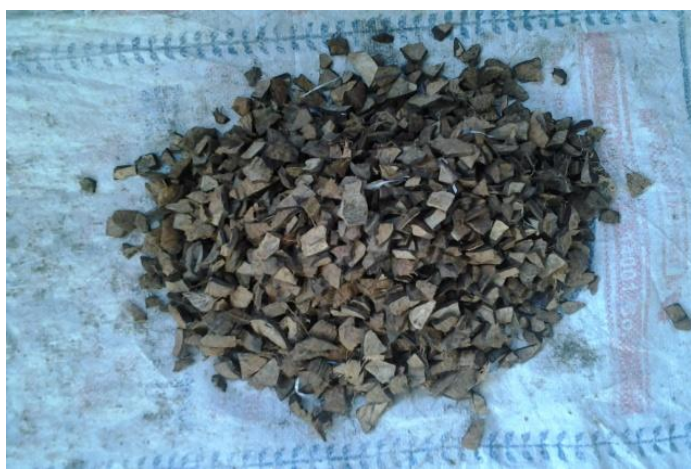

Figure 3: Coconut shell as aggregates

III.

EXPERIMENTAL PROGRAMME

The target of the experimental program was to determine the contribution of natural material aggregate type to the development of the strength behaviour of the confined concrete. The experimental program comprises the following:

a. To Compute and compare the Compressive strength of M20, M35 \& M50 mix concrete cube specimens with $10 \%, 20 \%, 30 \% \& 40 \%$ replacement of aggregate by coconut shell concrete cube specimens.

b. To check various properties of coconut shell concrete mix like

- Density

- $\quad$ Modulus of Elasticity

- Workability

- Water-cement ratio

- Water absorption

- Slump cone

c. To investigate the feasibility of the combination of coconut shell as coarse aggregate in concrete by determining its compressive strength and durability.

d. To investigate the effect of the combination of coconut shell as coarse aggregate in concrete content and length to the workability as lightweight aggregate in concrete.

e. To determine the optimum content of the combination of coconut shell as coarse aggregate in concrete to improve the ductility and does not cause reduction in the compressive strength.

f. To compute applications of such lightweight concrete in construction \& its economy.

\section{COCONUT SHELL BLENDED CONCRETE}

Based on the literature review and research planning, the expected outcomes for the Research are: 
4.1 Work plan -

\begin{tabular}{|c|c|c|c|}
\hline Sr. No. & Concrete Cube & 7 Days & 28 Days \\
& & & \\
\hline $\mathbf{1}$ & M 20 Mix & 3 & 3 \\
\hline $\mathbf{2}$ & $20 \%$ replacement Aggregate by Coconut Shell & 3 & 3 \\
\hline $\mathbf{3}$ & $30 \%$ replacement Aggregate by Coconut Shell & 3 & 3 \\
\hline $\mathbf{4}$ & 40\% replacement Aggregate by Coconut Shell & 3 & 3 \\
\hline $\mathbf{5}$ & M 35 Mix & 3 & 3 \\
\hline $\mathbf{6}$ & 20\% replacement Aggregate by Coconut Shell & 3 & 3 \\
\hline $\mathbf{7}$ & $30 \%$ replacement Aggregate by Coconut Shell & 3 & 3 \\
\hline $\mathbf{8}$ & 40\% replacement Aggregate by Coconut Shell & 3 & 3 \\
\hline $\mathbf{9}$ & M 50 Mix & 3 & 3 \\
\hline $\mathbf{1 0}$ & 20\% replacement Aggregate by Coconut Shell & 3 & 3 \\
\hline $\mathbf{1 1}$ & $30 \%$ replacement Aggregate by Coconut Shell & 3 & 3 \\
\hline $\mathbf{1 2}$ & 40\% replacement Aggregate by Coconut Shell & 3 & 3 \\
\hline \multicolumn{2}{|r}{ TOTAL CUBES CAST } & $\mathbf{3 6}$ & $\mathbf{3 6}$ \\
\hline
\end{tabular}

Total no. Of samples - 72

V. FLOWCHART OF WORK
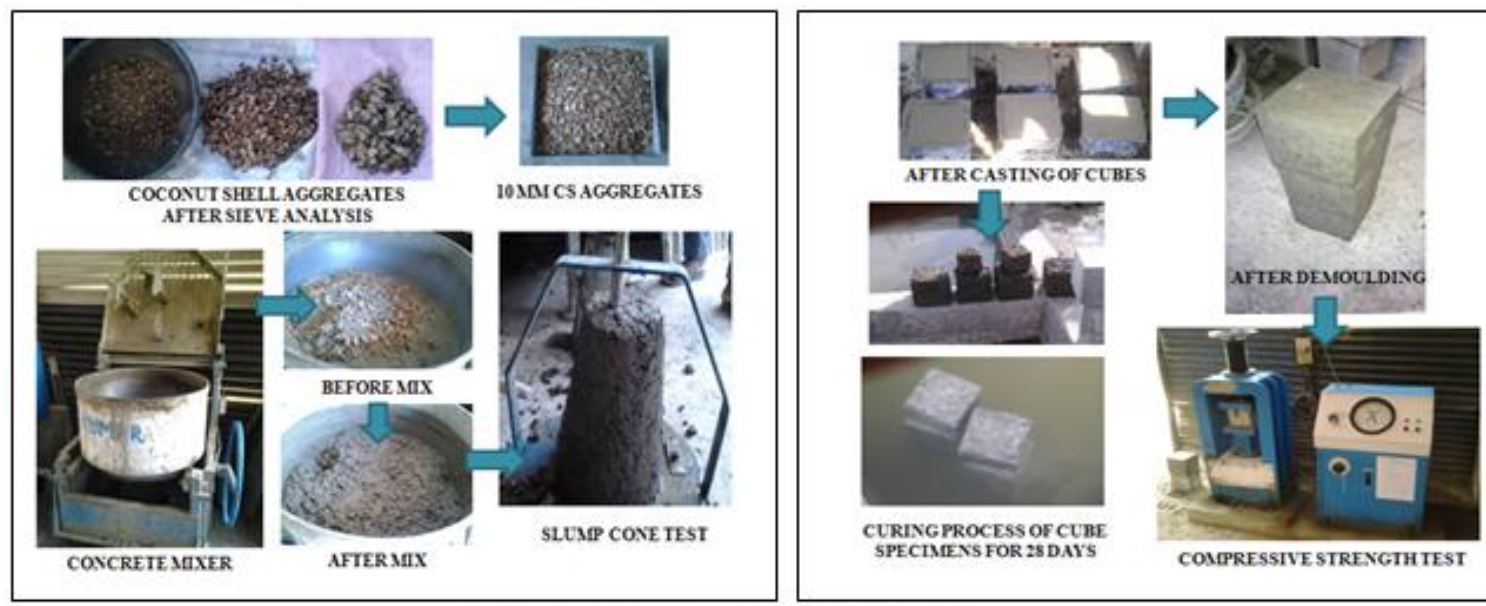

Figure 4: Flowchart of Actual Lab Work

VI. LAB PROCESS

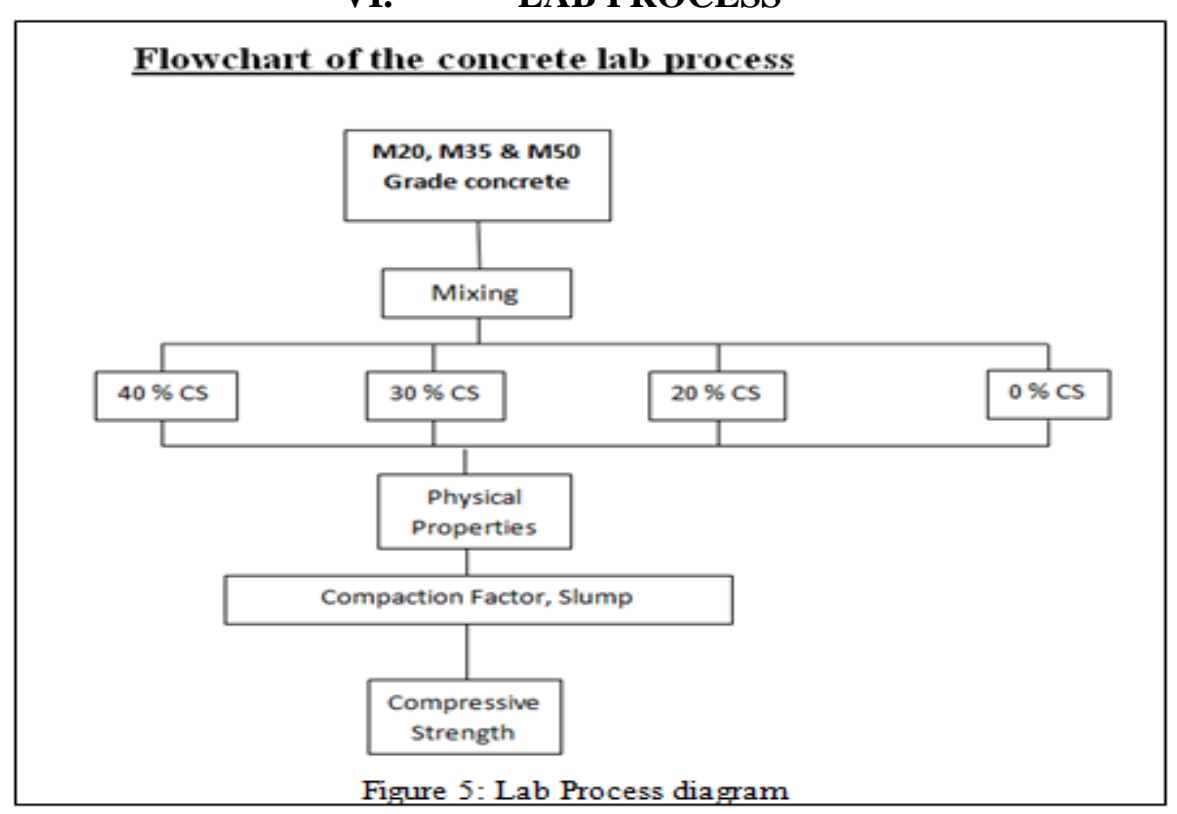


6.1 Compressive strength data sheet:

\begin{tabular}{cccccccc}
\hline \multirow{2}{*}{ Trial } & Trial details & \multicolumn{7}{c}{ Compressive Strength (in Mpa) } \\
\cline { 3 - 8 } M20 grade & Trial I & 26.67 & 24.44 & 20.44 & 31.11 & 32.44 & 30.66 \\
& 7/01/2014 & $(14 / 1)$ & $(14 / 1)$ & $(14 / 1)$ & $(4 / 2)$ & $(4 / 2)$ & $(4 / 2)$ \\
M20 - 20\% CS & Trial II & 20 & 21.77 & 20 & 28 & 32.88 & 30.22 \\
& $23 / 01 / 2014$ & $(30 / 1)$ & $(30 / 1)$ & $(30 / 1)$ & $(20 / 2)$ & $(20 / 2)$ & $(20 / 2)$ \\
M20 - 30\% CS & Trial III & 18.66 & 20.88 & 20.44 & 21.33 & 23.11 & 24.44 \\
& $24 / 01 / 2014$ & $(31 / 1)$ & $(31 / 1)$ & $(31 / 1)$ & $(21 / 2)$ & $(21 / 2)$ & $(21 / 2)$ \\
M35 - 20\% CS & Trial IV & 31.11 & 35 & 33.33 & 48.33 & 50.11 & 49.20 \\
& $28 / 01 / 2014$ & $(4 / 2)$ & $(4 / 2)$ & $(4 / 2)$ & $(25 / 2)$ & $(25 / 2)$ & $(25 / 2)$ \\
M35 - 30\% CS & Trial V & 26.22 & 26.66 & 26.22 & 37.77 & 42.22 & 44.44 \\
& $30 / 01 / 2014$ & $(6 / 2)$ & $(6 / 2)$ & $(6 / 2)$ & $(27 / 2)$ & $(27 / 2)$ & $(27 / 2)$ \\
M50 - 20\% CS & Trial VI & 32.44 & 31.11 & 33.33 & 56.66 & 56.44 & 54.55 \\
& $1 / 02 / 2014$ & $(8 / 2)$ & $(8 / 2)$ & $(8 / 2)$ & $(1 / 3)$ & $(1 / 3)$ & $(1 / 3)$ \\
M50 - 30\% CS & Trial VII & 36 & 36.44 & 35.55 & 51.11 & 48.88 & 50.66 \\
& $5 / 02 / 2014$ & $(12 / 2)$ & $(12 / 2)$ & $(12 / 2)$ & $(5 / 3)$ & $(5 / 3)$ & $(5 / 3)$ \\
M35 grade & Trial VIII & 34.66 & 36 & 35.55 & 57.33 & 57.77 & 58.22 \\
& $8 / 02 / 2014$ & $(15 / 2)$ & $(15 / 2)$ & $(15 / 2)$ & $(8 / 3)$ & $(8 / 3)$ & $(8 / 3)$ \\
M50 grade & Trial IX & 42.22 & 44.44 & 42.66 & 61.33 & 57.33 & 59.55 \\
& $8 / 02 / 2014$ & $(15 / 2)$ & $(15 / 2)$ & $(15 / 2)$ & $(8 / 3)$ & $(8 / 3)$ & $(8 / 3)$ \\
M20 - 40\% CS & Trial X & 5.77 & 6.22 & 4.45 & 9.33 & 8.44 & 8.44 \\
& $10 / 02 / 2014$ & $(17 / 2)$ & $(17 / 2)$ & $(17 / 2)$ & $(10 / 3)$ & $(10 / 3)$ & $(10 / 3)$ \\
M35 - 40\% CS & Trial XI & 12 & 11.11 & 12 & 14 & 15.28 & 15.52 \\
& $15 / 02 / 2014$ & $(22 / 2)$ & $(22 / 2)$ & $(22 / 2)$ & $(15 / 3)$ & $(15 / 3)$ & $(15 / 3)$ \\
M50 - 40\% CS & Trial XII & 15.11 & 13.77 & 18.22 & 22.22 & 22.66 & 21.33 \\
& $10 / 02 / 2014$ & $(17 / 2)$ & $(17 / 2)$ & $(17 / 2)$ & $(10 / 3)$ & $(10 / 3)$ & $(10 / 3)$ \\
\hline
\end{tabular}

6.2 Testing of cube specimen:
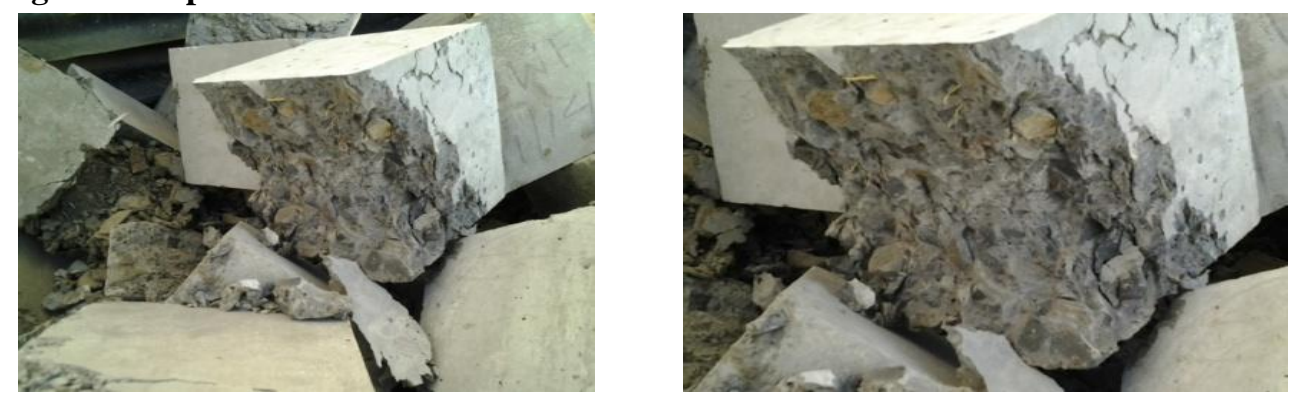

Figure 6: Coconut Shell Blended Concrete Cube Specimen after Test

\section{RESULT ANALYSIS}

Every result is shown by graph representing strength due to course of time in $7 \& 28$ days.

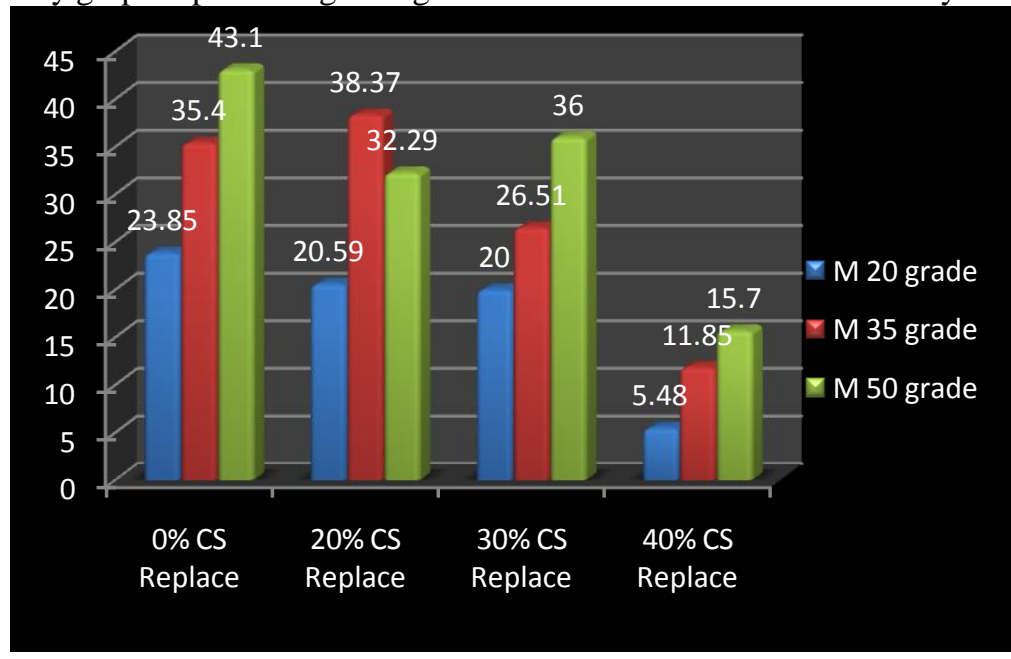

Graph 1: Comparison of Compressive strength analysis of CS concrete at 7 Days 


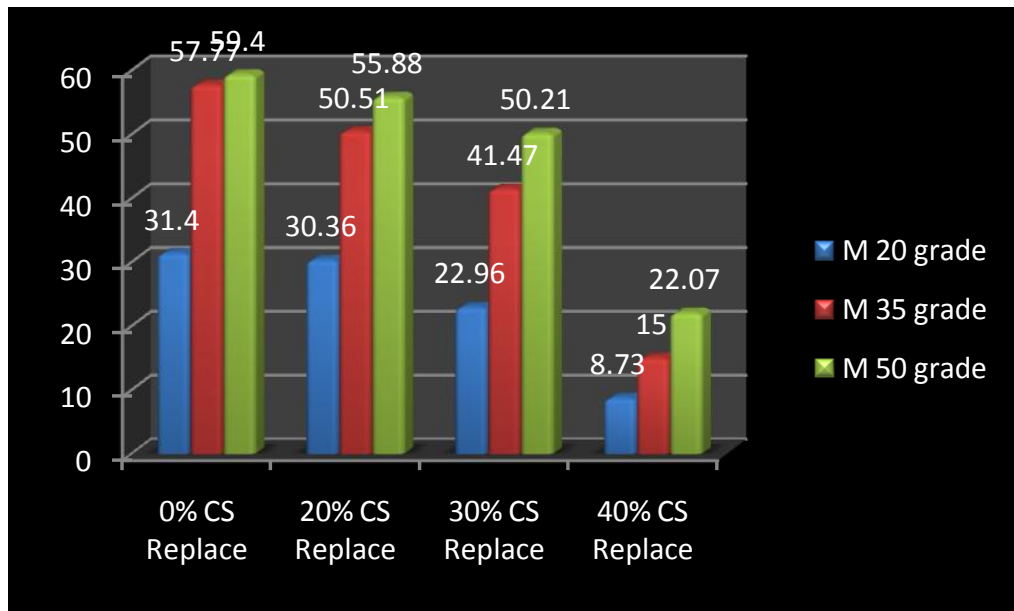

Graph 2: Comparison of Compressive strength analysis of CS concrete at 28 Days

1. From Graph 2, for M20 grade concrete cubes with $30 \%$ replacement of CS aggregates had given requisite strength of $23 \mathrm{Mpa}$ at 28 days. Hence, it can be used with proportions varying from $0-30 \%$.

2. From Graph 2, for M35 grade concrete cubes with 30\% replacement of CS aggregates had given strength of $42 \mathrm{Mpa}$ at 28 days.

3. From Graph 2, for M50 grade concrete cubes with $30 \%$ replacement of CS aggregates had given requisite strength of $51 \mathrm{Mpa}$ at 28 days. Further we can replace CS up to $40 \%$ which gives M20 grade concrete strength so; we can use it as M20 grade concrete up to $40 \%$ CS replaced for low cost housing \& the places where it is easily available.

\subsection{Cost Analysis:}

Cost of concrete is depending upon the quantity, quality \& proportion of materials used. Coconut shell in concrete not only changes the strength property of concrete but also changes the cost of that particular design.

Table 7.1: Cost analysis for M20 grade of project - for $1 \mathrm{~m}^{3}$ of concrete

\begin{tabular}{|c|c|c|c|c|c|}
\hline Material & Rate (Rs.) & \multicolumn{4}{|c|}{ Cost of concrete (Rs.) } \\
\hline & & P.C.C. & $\begin{array}{c}\mathbf{2 0 \%} \text { CS } \\
\text { replace } \\
\text { Concrete }\end{array}$ & $\begin{array}{c}\mathbf{3 0 \%} \text { CS } \\
\text { replace } \\
\text { Concrete }\end{array}$ & $\begin{array}{c}\mathbf{4 0 \%} \text { CS } \\
\text { replace } \\
\text { Concrete }\end{array}$ \\
\hline Cement & $6.4 / \mathrm{kg}$ & 2080 & 2080 & 2080 & 2080 \\
\hline Fly ash & $0.5 / \mathrm{Kg}$ & - & - & - & - \\
\hline Crushed Sand & $2800 / \mathrm{br}$ & 545 & 545 & 545 & 545 \\
\hline 10mm Aggregate & $2300 / \mathrm{br}$ & 250 & 200 & 175 & 150 \\
\hline 20mm Aggregate & $2300 / \mathrm{br}$ & 305 & 305 & 305 & 305 \\
\hline Admixture & $35 / \mathrm{Kg}$ & 113 & 113 & 113 & 113 \\
\hline & Total (Rs.) & $\mathbf{3 2 9 3 / -}$ & $\mathbf{3 2 4 3 / -}$ & $\mathbf{3 2 1 8} /-$ & $\mathbf{3 1 9 3 / -}$ \\
\hline
\end{tabular}

Table 7.2: Cost analysis for M35 grade of project - for $1 \mathrm{~m}^{3}$ of concrete

\begin{tabular}{|c|c|c|c|c|c|}
\hline \multirow{2}{*}{ Material } & Rate (Rs.) & \multicolumn{5}{|c|}{ Cost of concrete (Rs.) } \\
\hline & & P.C.C. & $\begin{array}{c}\text { 20\% CS replace } \\
\text { Concrete }\end{array}$ & $\begin{array}{c}\text { 30\% CS replace } \\
\text { Concrete }\end{array}$ & $\begin{array}{c}\text { 40\% CS replace } \\
\text { Concrete }\end{array}$ \\
\hline Cement & $6.4 / \mathrm{kg}$ & 2624 & 2624 & 2624 & 2624 \\
\hline Fly ash & $0.5 / \mathrm{Kg}$ & - & - & - & - \\
\hline Crushed Sand & $2800 / \mathrm{br}$ & 521 & 521 & 521 & 521 \\
\hline $10 \mathrm{~mm}$ Aggregate & $2300 / \mathrm{br}$ & 212 & 169.6 & 148.5 & 127 \\
\hline $20 \mathrm{~mm}$ Aggregate & $2300 / \mathrm{br}$ & 318 & 318 & 318 & 318 \\
\hline Admixture & $35 / \mathrm{Kg}$ & 144 & 144 & 144 & 144 \\
\hline & Total (Rs.) & $\mathbf{3 8 1 9 / -}$ & $\mathbf{3 7 7 7 / -}$ & $\mathbf{3 7 5 6 / -}$ & $\mathbf{3 7 3 4 / -}$ \\
\hline
\end{tabular}


Table 7.3: Cost analysis for M50 grade of project - for $1 \mathrm{~m}^{3}$ of concrete

\begin{tabular}{|c|c|c|c|c|c|}
\hline \multirow[t]{2}{*}{ Material } & \multirow[t]{2}{*}{$\begin{array}{l}\text { Rate } \\
\text { (Rs.) }\end{array}$} & \multicolumn{4}{|c|}{ Cost of concrete (Rs.) } \\
\hline & & P.C.C. & $\begin{array}{l}20 \% \mathrm{CS} \\
\text { replace } \\
\text { Concrete }\end{array}$ & $\begin{array}{c}30 \% \mathrm{CS} \\
\text { replace } \\
\text { Concrete }\end{array}$ & $\begin{array}{l}40 \% \mathrm{CS} \\
\text { replace } \\
\text { Concrete }\end{array}$ \\
\hline Cement & $6.4 / \mathrm{kg}$ & 3200 & 3200 & 3200 & 3200 \\
\hline Fly ash & $0.5 / \mathrm{Kg}$ & - & - & - & - \\
\hline $\begin{array}{l}\text { Crushed } \\
\text { Sand }\end{array}$ & $2800 / \mathrm{br}$ & 442 & 442 & 442 & 442 \\
\hline $\begin{array}{c}10 \mathrm{~mm} \\
\text { Aggregate }\end{array}$ & $2300 / \mathrm{br}$ & 195 & 156 & 136.5 & 117 \\
\hline $\begin{array}{c}20 \mathrm{~mm} \\
\text { Aggregate }\end{array}$ & $2300 / \mathrm{br}$ & 362 & 362 & 362 & 362 \\
\hline Admixture & $35 / \mathrm{Kg}$ & 168 & 168 & 168 & 168 \\
\hline & $\begin{array}{l}\text { Total } \\
\text { (Rs.) }\end{array}$ & 4367/- & $4328 /-$ & 4309/- & 4289/- \\
\hline
\end{tabular}

\section{CONCLUSION}

a. From the experimental results and discussion, the coconut shell has potential as lightweight aggregate in concrete. Also, using the coconut shell as aggregate in concrete can reduce the material cost in construction because of the low cost and abundant agricultural waste. Coconut Shell Concrete can be used in rural areas and places where coconut is abundant and may also be used where the conventional aggregates are costly. Coconut shell concrete is also classified as structural lightweight concrete.

b. It is concluded that the Coconut Shells are more suitable as low strength-giving lightweight aggregate when used to replace common coarse aggregate in concrete production.

c. Trying to replace aggregate by coconut shell partially to make concrete structure more economic along with good strength criteria.

d. From one cube calculation bulk amount of shell replacement can be evaluated \& reduces over all construction cost.

e. This can be useful for construction of low cost housing society.

\section{FUTURE SCOPE}

a. Well grinded pieces of these wastes should be checked for the replacement of fine aggregates i.e. for sand in concrete mix.

b. Durability factor can be determined by carrying some durability tests on the CS cube specimens.

c. Flexural strength can also be determined by casting CS concrete cube specimens.

d. Light weight construction units can be made by using these wastes like panels \& block production, internal wall casting, outdoor furniture etc.

e. Combination with fly ash can also be an option for future experimentation.

f. Other wastes like Sugarcane bagasse, blast furnace slag \& Plastic can be an option for waste utilization in construction practices.

\section{ACKNOWLEDGEMENT}

The authors express their sincere gratitude to the Principal, Dr. D Y Patil School of Engineering and Technology, Lohgaon, Pune, India for encouragement and granting permission for this project and also to publish this project. The authors would also like to thank to Mr. Yusuf Inamdar Sir of J. Kumar Infraprojects LTD to give Sponsorship for this work. Authors acknowledge the support received from the department and well wishers.

\section{Journal Papers:}

\section{REFERENCES}

[1] Olanipekun, E.A., Olusola, K.O. \& Ata, O, A comparative study of concrete properties using coconut shell \& palm kernel shell as coarse aggregates, Building and Environment 41:297-301,2006.

[2] Gopal Charan Behera, Ranjan Kumar Behera, Coconut Shell as Coarse Aggregate, International Journal of Engineering Research \& Technology (IJERT), vol.2, Issue 6, June - 2013.

[3] Amarnath Yerramala Ramachandrudu C, Properties of Concrete with Coconut Shells as Aggregate Replacement, International Journal of Engineering Inventions, vol.1, Issue 6, October 2012. 
[4] Abdulfatah Abubakar and Muhammed Saleh Abubakar, Exploratory Study of Coconut Shell as Coarse Aggregate in Concrete, Journal of Engineering \& Applied sciences, vol.3, December 2011.

[5] Daniel Yaw Osei, Experimental assessment on coconut shells as aggregate in concrete, International Journal of Engineering Science Invention, vol. 2, Issue 5, May 2013.

[6] Maninder Kaur \& Manpreet Kaur, Review On Utilization Of Coconut Shell As Coarse Aggregates in Mass Concrete, International Journal of Applied Engineering Research, vol.7, Issue 11, 2012.

\section{References from Books:}

[7] M. S. Shetty "Concrete Technology"- S. Chand Publication House 2008

[8] M. L. Gambhir "Concrete Technology"- Tata McGraw Hill book, New York

IS Codes:

[9] IS 10262:1982, Recommended guidelines for concrete mix design.

[10] IS 456:2000, Plain \& Reinforced concrete - Code of Practice

[11] IS 383:1970, Specification for Coarse \& fine aggregates from natural sources for Concrete.

Article:

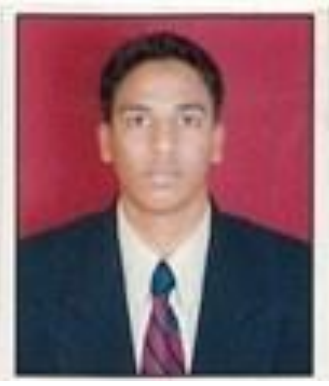

Parag Shantaram Kambli

[M.E. - Civil (Structure)],

PG Student, DYPSOET, Lohgaon, Pune.

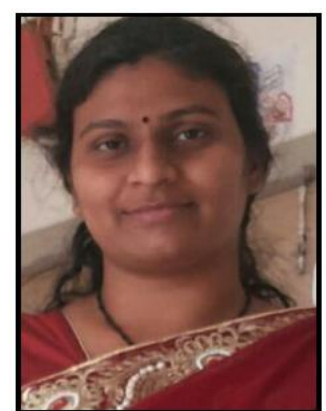

Sandhya R. Mathapati

M.E. - Civil (Structure),

Project Guide, DYPSOET, Lohgaon, Pune. 